\title{
Hydrolysis of phytic acid and its availability in rabbits
}

\author{
M. Marounek ${ }^{1 *}$, D. Dušková ${ }^{1}$ and V. Skřivanová ${ }^{2}$ \\ ${ }^{1}$ Institute of Animal Physiology and Genetics, Czech Academy of Sciences, \\ Prague 10, Uhř́něves, CZ-104 00, Czech Republic \\ ${ }^{2}$ Research Institute of Animal Production, Prague 10, Uhř́něves, CZ-104 01, Czech Republic
}

(Received 5 November 2001 - Revised 26 September 2002 - Accepted 30 September 2002)

\begin{abstract}
Twenty weaned rabbits were fed ad libitum two granulated feeds containing lucerne meal, barley, oats, wheat bran, oilseed meals and sugarbeet pulp in different proportions. Phytate $\mathrm{P}$ in these feeds represented 28.6 and $29.3 \%$ of the total P. Digestibility trials were carried out in rabbits 7 and 10 weeks old. Digestibility of phytate P was $82.1 \%$, on average. Apparent digestibility of total $\mathrm{P}$ was 48.1 and $35.5 \%$ in rabbits aged 7 and 10 weeks, respectively. Concentration of $\mathrm{P}$ in the faecal DM of these rabbits averaged 11.9 and $14.7 \mathrm{mg} / \mathrm{g}$. Most of the faecal $\mathrm{P}$ was phosphates $\mathrm{P}(68.1 \%)$. Proportion of phytate $\mathrm{P}$ in total faecal $\mathrm{P}$ was $9.0 \%$. Age effect on total $\mathrm{P}$ digestibility and faecal $\mathrm{P}$ concentration was significant $(P<0.05)$. In five in vitro experiments twenty-four rabbits were killed at the age of 11 weeks, digesta samples diluted with physiological saline containing phytic acid and incubated anaerobically. Calculations of phytase activity in segments of the digestive tract were based on the estimation of phytic acid hydrolysed during the first $2 \mathrm{~h}$ of incubation. The caecum contained $58.6 \%$ of the phytase activity of the digestive tract. Corresponding relative values for the phytase activity in the stomach, small intestine and colon were $22 \cdot 3,7 \cdot 7$ and $11.4 \%$, respectively. In incubations of the caecal contents, phytic acid was hydrolysed more rapidly at $\mathrm{pH} 5-6$ than in the neutral $\mathrm{pH}$ region. The hydrolysis was inhibited by $\mathrm{Ca}$ cations, and to a small extent also by phosphate anions. Commercial fungal phytase (Natuphos ${ }^{\circledR}$ ) was highly active in incubations of the contents of the stomach at $\mathrm{pH}$ 1.9. It can be concluded that phytic acid is hydrolysed quite efficiently in the digestive tract of rabbits. This hydrolysis occurred mainly in the caecum. Absorption of soluble inorganic phosphates in the gut is incomplete.
\end{abstract}

Rabbits: Phytic acid: Phosphorus: Digestibility

Feeds of intensively reared rabbits contain high proportions of cereal grains, cereal by-products and oilseed meals (de Blas \& Mateos, 1998). The primary form of $\mathrm{P}$ in these ingredients is phytic acid present as a salt (phytate) of mono- and divalent cations. Ruminants utilize phytate $\mathrm{P}$ very well, thanks to symbiotic microflora in the rumen (Raun et al. 1956; Morse et al. 1992; Yanke et al. 1998). In contrast, phytate is rather poorly digested in single-stomached animals. In growing pigs, the availability of phytate $\mathrm{P}$ has been found to range from 20 to $60 \%$ (for a review, see Reddy et al. 1982). In poultry, the phytate $\mathrm{P}$ utilization ranges from 0 to over $50 \%$ (for a review, see Ravindran et al. 1995). Rodents can utilize variable amounts of phytate P. Taylor \& Coleman (1979) compared the ability of rats and hamsters to utilize $\mathrm{P}$ from four diets varying in their content of $\mathrm{Ca}(5 \cdot 1$ and $10.8 \mathrm{~g}$ $\mathrm{Ca} / \mathrm{kg}$ ) and phytate $(1.6$ and $3.4 \mathrm{~g}$ phytate $\mathrm{P} / \mathrm{kg})$. Phytate $\mathrm{P}$ availability was significantly greater in hamsters
$(73.8-87.7 \%)$ than in rats $(32.6-66.1 \%)$ for all four diets. The ability of rabbits to utilise phytate $\mathrm{P}$ is not known. On one hand, the rabbit is a simple-stomached animal; on the other hand, it is a herbivore species with a complex microbial population in the hindgut. Mateos \& de Blas (1998) supposed that phytate P is well utilized in the rabbit because of phytase production by the microorganisms of the caecum and recycling of $\mathrm{P}$ through soft faeces and caecotrophy. Phytate $\mathrm{P}$ represented $4.0-11.0 \%$ of total $\mathrm{P}$ in faeces of rabbits fed a granulated concentrate feed containing $62 \%$ of ingredients rich in phytic acid: barley; oats; wheat bran; sunflower-seed meal (Marounek et al. 2000). Thus, the aim of the present study was: (i) to estimate digestibility of phytate $\mathrm{P}$ in rabbits fed concentrated feeds; (ii) to compare phytate hydrolysis in samples of digesta from the stomach, small intestine, caecum and colon; (iii) to identify factors influencing phytate hydrolysis in the rabbit caecum. 


\section{Materials and methods}

Animals and housing

Young medium-sized Hyplus ${ }^{\circledR}$ rabbits of both sexes, born in a commercial rabbitry, were used. Rabbits were weaned at the age of $35 \mathrm{~d}$ and housed individually in stainless steel mesh cages for the whole period of fattening (42d). Environmental conditions were as follows: temperature $16 \pm 1{ }^{\circ} \mathrm{C}$; relative humidity $65 \%$; daily photoperiod cycle $14 \mathrm{~h}$ light $-10 \mathrm{~h}$ dark.

\section{Digestibility trial}

Twenty weaned rabbits were divided into two groups and fed ad libitum diets I and II of different composition (Table 1). Diet I represented a standard fattening diet high in starch. Diet II contained less cereals and more wheat bran and sugarbeet pulp to decrease susceptibility of young rabbits to digestive disorders (Jehl \& Gidenne, 1996). The concentration of total and phytate $P$ in both diets was similar. The animals were provided with feed in the form of granules $3 \mathrm{~mm}$ in diameter. Feed consumption was recorded weekly. During the 7 th and 10th week of age, total faeces were collected to determine the apparent digestibility of nutrients according to Perez et al. (1995).

\section{Digesta sampling and incubations}

Twenty-four rabbits were fed with the granulated diet I and slaughtered sequentially at the age of 11 weeks to perform in vitro experiments. Eight rabbits were slaughtered at 9.00 hours, segments of their digestive tract (stomach, small intestine, caecum and colon) were emptied by gentle squeezing, and $\mathrm{pH}$ of the digesta was measured

Table 1. Composition of rabbit diets

\begin{tabular}{lcc}
\hline & Diet I & Diet II \\
\hline Ingredients (\%) & & \\
Lucerne meal & $28 \cdot 5$ & 16 \\
Barley & 19 & 13 \\
Wheat bran & 17 & 21 \\
Oat & 16 & 8 \\
Extracted sunflower-seed meal & $5 \cdot 5$ & 10 \\
Extracted soyabean meal & 4 & $2 \cdot 5$ \\
Yeast & 5 & 5 \\
Sugarbeet pulp & $2 \cdot 5$ & 20 \\
Rapeseed oil & $1 \cdot 5$ & $1 \cdot 5$ \\
Vitamin supplement & 1 & 1 \\
Limestone & 1 & 1 \\
Dicalcium phosphate & $0 \cdot 7$ & $0 \cdot 7$ \\
NaCl & $0 \cdot 3$ & $0 \cdot 3$ \\
Nutrients (g/kg) & & \\
DM & 911 & 909 \\
Starch & 217 & 174 \\
Crude protein & 168 & 169 \\
Fibre & 161 & 152 \\
Ash & 70 & 66 \\
Fat & 29 & 29 \\
Ca & $11 \cdot 3$ & $10 \cdot 7$ \\
P & $7 \cdot 29$ & $7 \cdot 14$ \\
Phytic acid* & $7 \cdot 41$ & $7 \cdot 44$ \\
\hline
\end{tabular}

* Phytic acid contains $28.15 \%$ P. immediately. Contents of individual segments were weighed. Samples of digesta $(5 \mathrm{~g})$ were diluted with $45 \mathrm{ml}$ warm $\left(39^{\circ} \mathrm{C}\right) \mathrm{O}_{2}$-free physiological saline containing sodium salt of phytic acid (no. P 3168, Sigma, Aldrich Ltd, Prague, Czech Republic) at $2 \mathrm{~mm}$ (final concentration). Diluted digesta samples were incubated under a $\mathrm{CO}_{2}$ atmosphere in a shaking water bath at $39^{\circ} \mathrm{C}$ for $6 \mathrm{~h}$. Incubations were carried out in $100 \mathrm{ml}$ bottles, hermetically sealed by rubber stoppers. The $\mathrm{pH}$ of cultures was measured at hourly intervals and controlled manually by injecting $6 \%$ (v/v) $\mathrm{HCl}$ or $5 \mathrm{M}-\mathrm{NaOH}$. Gastric, small-intestinal, caecal and colonic samples were incubated at $\mathrm{pH} 1.9$ (SD 0.1), $6.5(\mathrm{SD} 0.3), 6 \cdot 2(\mathrm{SD} 0 \cdot 3)$ and $6.5(\mathrm{SD} 0.3)$, respectively, i.e. at $\mathrm{pH}$ similar to in vivo values. At $2 \mathrm{~h}$ time intervals, samples of the incubation fluid were removed by means of a syringe, heated to $100^{\circ} \mathrm{C}$ for $4 \mathrm{~min}$ to stop enzymic reactions, and stored at $-20^{\circ} \mathrm{C}$ before analysis. In four 11-week-old rabbits, the contents of the stomach were incubated at pH 1.9 (SD 0.1) with or without the fungal phytase addition. Phytase (Natuphos ${ }^{\circledR}$; BASF Ludwigshafen, Germany) was added at $0.3 \mathrm{U} / \mathrm{ml}$. Samples of the incubation fluid were taken at $0,20 \mathrm{~min}, 1,2,4$ and $6 \mathrm{~h}$. In a separate experiment, digesta samples were diluted and heated to $100^{\circ} \mathrm{C}$ for $15 \mathrm{~min}$ before substrate addition to prevent enzymic hydrolysis of phytic acid. Samples were incubated at $39^{\circ} \mathrm{C}$ for $6 \mathrm{~h}$.

Four rabbits were slaughtered at 9.00 hours, their caeca were emptied, and pooled caecal contents mixed. A sample of the caecal contents $(50 \mathrm{~g})$ was diluted with $450 \mathrm{ml}$ physiological saline containing phytic acid, as described earlier. Incubations were carried out in six $500 \mathrm{ml}$ bottles, closed by rubber bungs with ports for sampling, gas entry and exit. In two bottles, the $\mathrm{pH}$ was maintained around 5.0, in two bottles around 6.0, and in two bottles at about 6.9 . The $\mathrm{pH}$ was measured at hourly intervals and controlled manually by the addition of $6 \%(\mathrm{v} / \mathrm{v}) \mathrm{HCl}$ or $5 \mathrm{M}-\mathrm{NaOH}$. Samples of the incubation fluid were treated as described earlier and stored at $-20^{\circ} \mathrm{C}$ until they could be analysed.

The same procedure was used to assess the effect of $\mathrm{Ca}$ and phosphate ions on hydrolysis of phytic acid. Ca was added to incubations as $\mathrm{CaCl}_{2}$ at $0,6,12$ and $18 \mu \mathrm{mol} /$ $\mathrm{ml}$. In the last experiment, phosphates were added to incubations of the caecal contents as $\mathrm{NaH}_{2} \mathrm{PO}_{4}$ at 0,20 and $40 \mu \mathrm{mol} / \mathrm{ml}$. The $\mathrm{pH}$ was maintained between 5.9 and 6.2 in these incubations.

\section{Analyses}

Phytic acid in the feeds and faeces was determined by a capillary isotachophoretic method described in detail previously (Dušková et al. 2001). In this method the molecules to be separated are sandwiched between a leading electrolyte with a high-mobility ion and a terminal electrolyte with a low-mobility ion. When the electric field is applied, the sample ions begin to sort themselves out into zones according to their mobilities. The zones remain in contact as there is no carrier electrolyte to fill the gap, but they do not mix. Faeces were freeze-dried before analyses. Phytic acid was extracted by $0.95 \mathrm{M}-\mathrm{HCl}$, separated from interfering compounds by precipitation with $\mathrm{FeCl}_{3}$, and ferric phytate dissolved by $1.5 \mathrm{M}-\mathrm{NaOH}$. The ferric 
hydroxide precipitate was removed by centrifugation, and the supernatant fraction neutralized by adding catex Dowex $50 \mathrm{WX} 8$ in $\mathrm{H}^{+}$-cycle. The solution was analysed using the column-coupling instrument EA 101 (Villa Labeco, Spišská Nová Ves, Slovakia). The phytic acid zone was identified on the basis of the step height using a standard solution. To be sure that the identification was correct, a pooled sample of rabbit faeces was extracted, precipitated with $\mathrm{FeCl}_{3}$, the precipitate dissolved in $\mathrm{NaOH}$, and $\mathrm{Fe}(\mathrm{OH})_{3}$ removed by centrifugation. The supernatant fraction was treated with phytase (Sigma, no. P 1259) as described by Dušková et al. (2001). Quantitative estimation of phytic acid was made via a regression equation between the concentration of phytic acid in extracts and the zone length in seconds. An external calibration method was used with solutions of the dodecasodium salt of phytic acid as standards. Phytic acid in all samples of the incubation fluid was determined using the same procedure, except that the $\mathrm{Fe}$ precipitation was omitted. After thawing, samples were mixed 1:1 with $1 \mathrm{M}-\mathrm{HCl}$ and treated with Dowex $50 \mathrm{WX} 8$ in $\mathrm{H}^{+}$-cycle at $50 \mu \mathrm{l} / \mathrm{ml}$. The mixture was shaken at room temperature for $1 \mathrm{~h}$ and centrifuged. The supernatant fraction was diluted 100 times with deionized water, neutralized by bis-tris propane (Sigma, no. B 6755) and analysed by isotachophoresis.

Volatile fatty acids in samples of the incubation fluid from the beginning and the end of caecal incubations were estimated by titration, after steam distillation. Total $\mathrm{P}$ in feeds and faeces was determined by a vanadomolybdate reagent, after ashing of dry samples at $550^{\circ} \mathrm{C}$ (Association of Official Analytical Chemists, 1980). Phosphates present in faeces were extracted by $5 \%(\mathrm{w} / \mathrm{v}) \mathrm{TCA}$, and determined by the Fiske and SubbaRow method, as modified by Peterson (1978). To determine the DM, feeds and faeces were air-dried at $105^{\circ} \mathrm{C}$ to constant weight. Contents of protein, fat and fibre were determined employing instruments
Kjeltec Auto 1030 Analyser, Soxtec 1043 and Fibertec 2010 from Tecator AB (SKA-TEC Ltd, Prague, Czech Republic) Company, respectively. Ca was assayed by atomic absorption spectrophotometry using a Perkin Elmer 5000 instrument (Perkin Elmer Ltd, Prague, Czech Republic).

\section{Calculations}

Calculation of phytase activity in segments of the rabbit digestive tract was based on the estimation of phytic acid hydrolysed to lower inositol phosphates during the first $2 \mathrm{~h}$ of in vitro incubation of digesta samples. One unit of enzyme activity was defined as the amount of enzyme that hydrolysed $1 \mu \mathrm{mol}$ phytic acid/h. The effect of age of rabbits on digestibility of nutrients and composition of faeces was evaluated by the $t$ test.

\section{Results}

No rabbit died and no digestive disorders except transitory diarrhoea occurred during the experiment. Final body weight at the age of 11 weeks was 2.73 (SD 0.25) and 2.61 (SD 0.29) $\mathrm{kg}$ in rabbits fed diet I and II, respectively. Fig. 1 shows isotachopherograms of the extracts of feed and faeces of rabbits. The zone of phytic acid was well separated from the zones of other compounds and disappeared in the extract treated with phytase. Samples of feeds and faeces contained small amounts of lower inositol phosphates.

Diets I and II contained 7.41 and $7.44 \mathrm{~g}$ phytic acid/ $/ \mathrm{kg}$, respectively (Table 1). Phytate $\mathrm{P}$ represented 28.6 and $29.3 \%$ of the total $\mathrm{P}$ in these diets. Average daily intake of phytic acid was 0.92 and $1.15 \mathrm{~g}$ at the age of 7 and 10 weeks, respectively (Table 2). Digestibility of phytate $\mathrm{P}$ was relatively high; 82.1 (SD 3.6) \%. It was not influenced by the age or diet of the rabbits. Apparent digestibility of total $\mathrm{P}$ was 48.4 and $47.8 \%$ in 7-week-old rabbits, and 38.5 and $32.4 \%$ in 10 -week-old rabbits fed diets I and II,

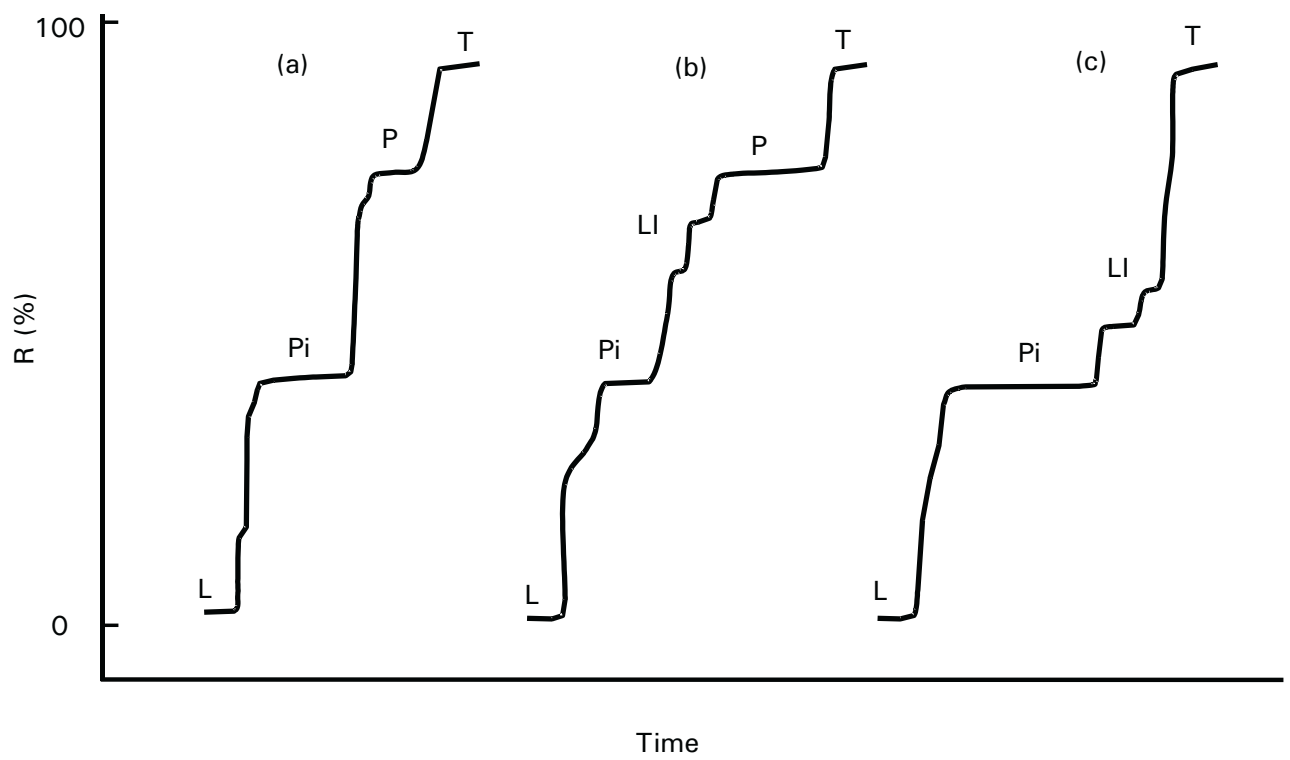

Fig. 1. Isotachopherograms of extracts of the feed (a) and faeces (b) and (c) of rabbits before (b) and after (c) treatment with phytase. $\mathrm{P}$, phytate; LI, lower inositol phosphates; Pi, inorganic phosphate; $\mathrm{L}$, leading ion; $\mathrm{T}$, terminating ion; $\mathrm{R}$, relative resistance. 
Table 2. Intake of feed, phytic acid and phosphorus, and digestibility of nutrients in rabbits fed concentrate diets I and II†

(Mean values and standard deviations for ten rabbits per diet)

\begin{tabular}{|c|c|c|c|c|c|c|c|c|}
\hline & \multicolumn{4}{|c|}{ Trial 1 (7th week of age) } & \multicolumn{4}{|c|}{ Trial 2 (10th week of age) } \\
\hline & \multicolumn{2}{|c|}{ Diet I } & \multicolumn{2}{|c|}{ Diet II } & \multicolumn{2}{|c|}{ Diet I } & \multicolumn{2}{|c|}{ Diet II } \\
\hline & Mean & SD & Mean & SD & Mean & SD & Mean & SD \\
\hline \multicolumn{9}{|l|}{ Intake (g/d) } \\
\hline Feed & 128 & 23 & 120 & 17 & $168^{*}$ & 12 & 142 & 40 \\
\hline Phytic acid & 0.95 & 0.17 & 0.89 & 0.13 & $1 \cdot 25^{\star}$ & 0.09 & 1.05 & 0.30 \\
\hline$P$ & 0.93 & 0.17 & 0.85 & $0 \cdot 12$ & $1.22^{*}$ & 0.09 & 1.01 & 0.29 \\
\hline \multicolumn{9}{|l|}{ Digestibility (\%) } \\
\hline Phytic acid & 83.3 & 3.4 & $81 \cdot 1$ & 4.9 & 83.2 & $2 \cdot 1$ & $80 \cdot 7$ & 3.9 \\
\hline $\mathrm{P}$ & 48.4 & 5.9 & $47 \cdot 8$ & 5.9 & $38.5^{*}$ & 4.5 & $32 \cdot 4^{*}$ & 3.9 \\
\hline DM & 65.5 & $2 \cdot 2$ & $65 \cdot 7$ & 2.5 & 64.5 & 1.7 & $65 \cdot 7$ & 1.6 \\
\hline Crude protein & 74.3 & 3.6 & $72 \cdot 3$ & 3.5 & 72.9 & 2.5 & $75 \cdot 6^{*}$ & 1.7 \\
\hline Fibre & 24.9 & 4.7 & $27 \cdot 4$ & 4.3 & $21 \cdot 3$ & 4.5 & $28 \cdot 1$ & 2.9 \\
\hline Ash & $58 \cdot 3$ & $2 \cdot 0$ & $50 \cdot 8$ & $5 \cdot 1$ & $55 \cdot 9^{*}$ & $2 \cdot 8$ & 47.5 & $3 \cdot 0$ \\
\hline Fat & 88.2 & $2 \cdot 3$ & $87 \cdot 0$ & $2 \cdot 0$ & 87.7 & $2 \cdot 3$ & 88.4 & 1.8 \\
\hline
\end{tabular}

* Mean values were significantly different from those of a corresponding value in 7 -week-old rabbits $(P<0.05)$.

†For details of diets and procedures, see Table 1 and p. 288.

respectively. Digestibility of $\mathrm{P}$ in 10-week-old rabbits was significantly lower than that in 7-week-old rabbits. As for other nutrients, the lowest and the highest digestibility was that of fibre $(21.3-28 \cdot 1 \%)$ and fat $(87 \cdot 0-88.4 \%)$, respectively. Intermediate digestibility values were those of ash (47.5-58.3\%), DM $(64.5-65 \cdot 7 \%)$ and protein $(72 \cdot 3-75 \cdot 6 \%)$.

Table 3 presents data on composition of rabbit faeces. The concentration of $\mathrm{P}$ in the faecal DM averaged 11.9 and $14.7 \mathrm{mg} / \mathrm{g}$ at the age of 7 and 10 weeks, respectively. Phytate P represented 9.0 (SD 2.0) \% of the total faecal $\mathrm{P}$. Its concentration in faeces significantly correlated with concentration of $\mathrm{Ca}(r 0.42 ; P<0.01)$ and ash $(r \quad 0.40$; $P<0.02)$. Most of the faecal $\mathrm{P}(68.1 \%$ on average $)$ was phosphates $\mathrm{P}$ extractable by $5 \%$ TCA. Also the concentration of phosphates in faeces significantly correlated with the concentration of $\mathrm{Ca}(r 0.42 ; P<0.01)$. Faeces of 10 -week-old rabbits contained significantly more phosphates and total $\mathrm{P}$ than faeces of 7-week-old rabbits.
The other results were obtained with rabbits fed the concentrate diet I. Phytic acid was hydrolysed more rapidly in incubations of the caecal and colonic contents than in incubations of digesta of the small intestine and the stomach (Fig. 2). No measurable non-enzymic hydrolysis of phytic acid occurred. In phytase-treated incubations of the gastric contents phytic acid concentration decreased to $8.6 \%$ of its initial value within $20 \mathrm{~min}$. No phytic acid was found in the incubation fluid $1 \mathrm{~h}$ after inoculation. Table 4 summarizes data on the specific and total phytase activity in the contents of segments of the rabbit digestive tract. The caecum contained more than half $(58.6 \%$, on average $)$ of the phytase activity present in the digestive tract. Corresponding values for the phytase activity present in the stomach, small intestine and colon were $22.3,7.7$ and $11.4 \%$, respectively. In in vitro incubations of the rabbit caecal contents, phytic acid was rapidly hydrolysed at $\mathrm{pH} 5.05 \pm 0.23$ and $\mathrm{pH}$ 6.00 (SD 0.16), but slowly at pH 6.93 (SD 0.14) (Fig. 3). The phytic acid hydrolysis was inhibited by $\mathrm{Ca}$ cations

Table 3. Content of phosphorus fractions, calcium and ash in faeces of rabbits fed concentrate diets I and II† (Mean values and standard deviations for ten rabbits per diet)

\begin{tabular}{|c|c|c|c|c|c|c|c|c|}
\hline & \multicolumn{4}{|c|}{ Trial 1 (7th week of age) } & \multicolumn{4}{|c|}{ Trial 2 (10th week of age) } \\
\hline & \multicolumn{2}{|c|}{ Diet I } & \multicolumn{2}{|c|}{ Diet II } & \multicolumn{2}{|c|}{ Diet I } & \multicolumn{2}{|c|}{ Diet II } \\
\hline & Mean & SD & Mean & SD & Mean & SD & Mean & SD \\
\hline Total P (mg/g DM) & $11 \cdot 9$ & $1 \cdot 1$ & 11.9 & 0.7 & $13 \cdot 9^{*}$ & $1 \cdot 0$ & $15 \cdot 5^{\star}$ & 0.6 \\
\hline Phytate P (mg/g DM) & $1 \cdot 12$ & 0.26 & $1 \cdot 23$ & 0.29 & 1.09 & 0.16 & $1 \cdot 30$ & 0.26 \\
\hline Phytate P/total P (\%) & $9 \cdot 4$ & $2 \cdot 7$ & $10 \cdot 3$ & $2 \cdot 8$ & $7 \cdot 8$ & $1 \cdot 1$ & $8 \cdot 4$ & 1.5 \\
\hline Phosphate P (mg/g DM) & $8 \cdot 3$ & 0.6 & $8 \cdot 6$ & 0.9 & $9 \cdot 0^{*}$ & 0.8 & $10 \cdot 2^{*}$ & $1 \cdot 1$ \\
\hline Phosphate P/total P (\%) & 69.7 & $7 \cdot 7$ & $72 \cdot 3$ & $6 \cdot 8$ & $64 \cdot 7$ & $7 \cdot 1$ & 65.8 & $6 \cdot 2$ \\
\hline $\mathrm{Ca}(\mathrm{mg} / \mathrm{g} \mathrm{DM})$ & $16 \cdot 9$ & $1 \cdot 0$ & $17 \cdot 0$ & 0.9 & $16 \cdot 6$ & $1 \cdot 0$ & $17 \cdot 3$ & $1 \cdot 2$ \\
\hline $\mathrm{Ca} / \mathrm{P}(\mathrm{mg} / \mathrm{mg})$ & 1.42 & 0.13 & 1.43 & 0.10 & $1 \cdot 19^{\star}$ & 0.05 & $1 \cdot 12^{*}$ & 0.07 \\
\hline Ash (mg/g DM) & $95 \cdot 6$ & 3.6 & $108 \cdot 9$ & 4.4 & 97.6 & 4.5 & $114 \cdot 8^{\star}$ & $2 \cdot 4$ \\
\hline
\end{tabular}

* Mean values were significantly different from those of a corresponding value in 7 -week-old rabbits $(P<0.05)$.

† For details of diets and procedures, see Table 1 and p. 288. 
(a)

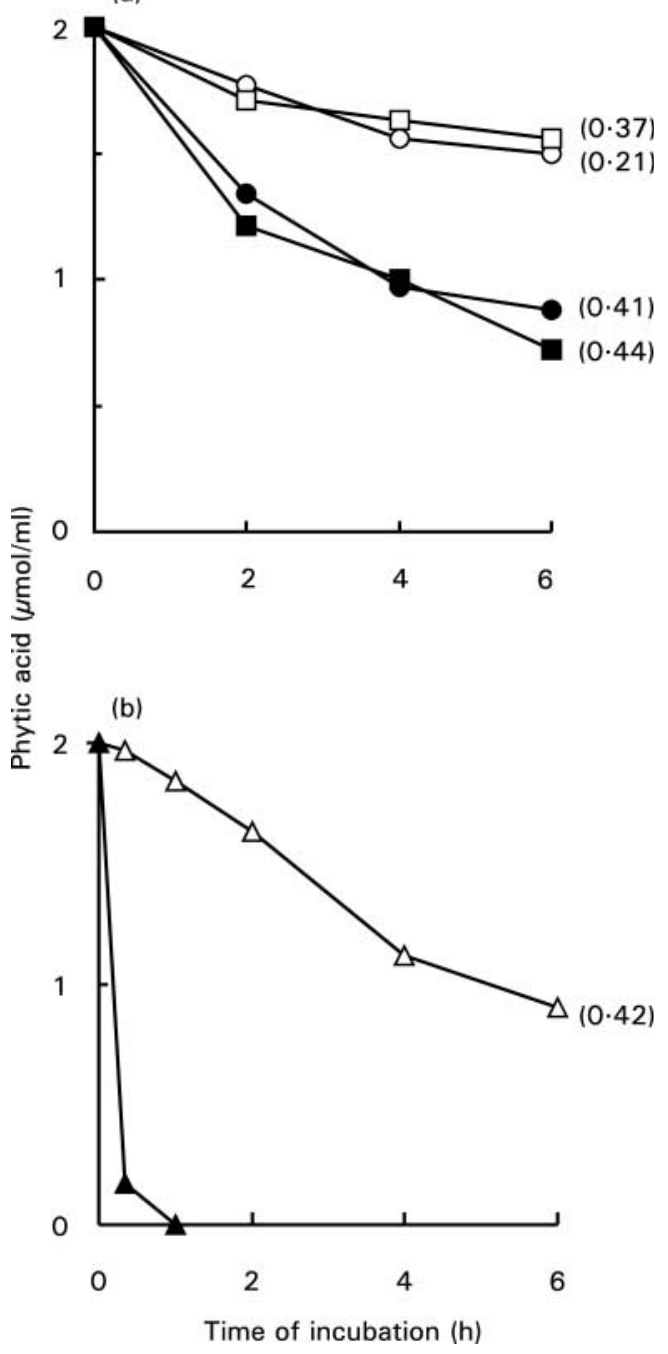

Fig. 2. Time course of phytic acid concentration in incubations of digesta samples of rabbits fed concentrate diet I. (a), Contents of stomach $(\bigcirc)$, small intestine $(\square)$, caecum $(\bullet)$ and colon $(\square)$ of eight rabbits were incubated individually; (b), contents of stomach of four rabbits were incubated with $(\boldsymbol{\Lambda})$ or without $(\Delta)$ phytase addition. Standard deviations of phytic acid concentration at the end of incubation are given in parentheses.

added to caecal incubations at the molar Ca:phytate ratio of 3:1, 6:1 and 9:1. Also phosphate anions inhibited phytic acid hydrolysis, however, to a small extent. Concentration of volatile fatty acids in samples of diluted caecal contents increased during incubation by $11.1-13.6 \mathrm{mmol} / \mathrm{l}$.

\section{Discussion}

The results of two digestibility trials showed that more than $80 \%$ of phytic acid was hydrolysed in the digestive tract of rabbits. This suggests that phytic acid hydrolysis was more efficient in rabbits than in pigs and poultry, but less efficient than in ruminants. Neither animal age ( 7 v. 10 weeks) nor partial replacement of starchy components of the feed by wheat bran and sugarbeet pulp affected the percentage of phytate recovered in the faeces. Small amounts of phytic acid were decomposed to lower inositol phosphates. It can be roughly estimated that these phosphates represent less than one-quarter of the total amount of $\mathrm{P}$ associated with inositol (Fig. 1). Properties of lower inositol phosphates, for example, their chelating potential, differ from those of phytic acid (Ravindran et al. 1995). Apparent total $\mathrm{P}$ digestibility was numerically much lower than phytic acid digestibility, mainly due to the gastrointestinal endogenous $\mathrm{P}$ secretion. In pigs, apparent digestibility values underestimate the true digestive utilization of $\mathrm{P}$ by about $25 \%$ (Fan et al. 2001). The digestibility of total $\mathrm{P}$ was significantly higher $(P<0.05)$ in 7 -week-old rabbits than in 10 -week-old rabbits by 9.9 and 15.4 percentage units on diets I and II, respectively (Table 2). A corresponding increase of faecal $\mathrm{P}$ concentration in 10-weekold rabbits was observed (13.9 and $15.5 \mathrm{mg} \mathrm{P} / \mathrm{g} \mathrm{DM}$ in 10 -week-old rabbits v. $11.9 \mathrm{mg} \mathrm{P} / \mathrm{g} \mathrm{DM}$ in 7-week-old rabbits). The concentration of phosphates in the faeces of older rabbits was also increased (Table 3).

In most mammalian species, phosphates are absorbed at the duodenal and jejunal level (Barlet et al. 1995). Intestinal brush-border membranes contain an $\mathrm{Na}^{+}$-phosphate cotransport system, which catalyses an electroneutral entry of phosphate and $\mathrm{Na}^{+}$into the intestinal epithelial cell (Berner et al. 1976). This system is the target for known physiological regulations. Hattenhauer et al. (1999) found that in mice amounts of $\mathrm{Na}^{+}$-phosphate co-transporters increased at low $\mathrm{P}$ intake. Other factors influencing expression of $\mathrm{Na}^{+}$-phosphate co-transporter protein are level of calcitriol and growth (Murer et al. 2001). The absorption of $\mathrm{P}$ in the intestine of rabbits is thus modulated both by dietary and endocrine factors. More efficient absorption of $\mathrm{P}$ in younger rabbits observed in the present study is probably mediated by endocrine factors as the diet composition was not changed. Better efficiency of $\mathrm{P}$ utilization in more rapidly growing animals presumably reflects their higher $\mathrm{P}$ requirement. Relative contributions of individual segments of the rabbit digestive tract to the

Table 4. Distribution of phytase activity in the digestive tract of 11-week-old rabbits fed concentrate diet I* (Mean values and standard deviations for eight rabbits)

\begin{tabular}{|c|c|c|c|c|c|c|c|c|}
\hline & \multicolumn{2}{|c|}{ Stomach } & \multicolumn{2}{|c|}{ Small intestine } & \multicolumn{2}{|c|}{ Caecum } & \multicolumn{2}{|c|}{ Colon } \\
\hline & Mean & SD & Mean & SD & Mean & SD & Mean & SD \\
\hline Digesta weight (g) & $119 \cdot 9$ & $17 \cdot 9$ & $32 \cdot 2$ & $10 \cdot 4$ & 111.5 & $23 \cdot 7$ & $19 \cdot 4$ & $10 \cdot 4$ \\
\hline $\mathrm{PH}$ & 1.45 & 0.21 & $7 \cdot 27$ & 0.24 & $6 \cdot 20$ & 0.24 & 6.58 & 0.43 \\
\hline Specific activity* ( $\mu \mathrm{mol}$ phytic acid hydrolysed/h per g digesta) & $1 \cdot 16$ & 0.46 & 1.49 & 0.93 & $3 \cdot 28$ & 1.46 & 3.68 & $1 \cdot 32$ \\
\hline Total activity $^{\star}$ ( $\mu \mathrm{mol}$ phytic acid hydrolysed/h per segment) & 139 & 54 & 48 & 42 & 366 & 231 & 71 & 51 \\
\hline
\end{tabular}

${ }^{*}$ For details of diets and procedures, see Table 1 and p. 288. 

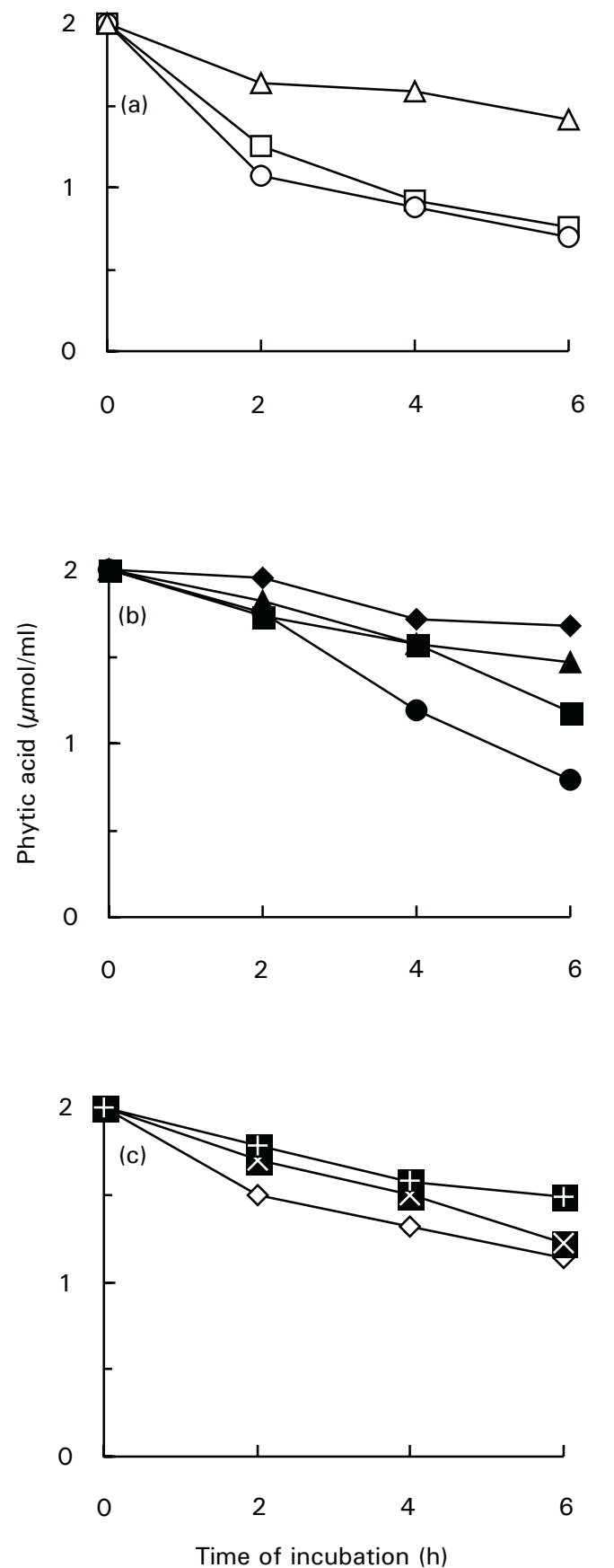

Fig. 3. Time course of phytic acid concentration in incubations of the caecal contents of rabbits fed concentrate diet I. (a), Caecal contents were incubated at pH 5.05 (SD 0.23) (O), pH 6.00 (SD 0.16) $(\square)$, and at pH 6.93 (SD 0.14) ( $\triangle$ ); (b), calcium chloride was added to incubations at $0(\bullet), 6(\square), 12(\mathbf{\Delta})$, and $18(\bullet) \mu \mathrm{mol} / \mathrm{ml}$; (c), monosodium phosphate was added to incubations at $0(\diamond), 20(\mathbf{X})$, and $40(\mathbb{H}) \mu \mathrm{mol} / \mathrm{ml}$. Pooled caecal contents of four rabbits were used in each experiment.

total P absorption are not known. In pigs, Fan et al. (2001) observed no difference between true ileal and faecal $\mathrm{P}$ digestibility. Of the total $\mathrm{P}$ in pig faeces, $40 \%$ was water-soluble inorganic phosphates, readily available for absorption. Liu et al. (2000) found a significant apparent absorption of $\mathrm{P}$ in the caecum of pigs when dietary $\mathrm{Ca}: \mathrm{P}$ was $1 \cdot 5$. When $\mathrm{Ca}: \mathrm{P}$ was $1 \cdot 0$, most of the $\mathrm{P}$ was absorbed in the small intestine. No apparent absorption of $\mathrm{P}$ occurred in the colon of pigs.

It follows from our results that phytic acid was hydrolysed more slowly in incubations of the gastric and small-intestinal contents than in those of the caecal and colonic contents. The gastric hydrolysis of phytic acid, however, cannot be neglected as the digesta is delayed in the rabbit stomach for several hours (Carabaño \& Piquer, 1998). Hydrolysis of phytic acid in the stomach can be explained by the phytase activity of the diet (which is variable, but not measured in the present study), and by the phytase supplied to the stomach by caecotrophy. Since the exogenous Aspergillus niger phytase was active in the incubations of the contents of the stomach at $\mathrm{pH} 1.9$, its addition to rabbit feeds would increase the pre-caecal phytic acid hydrolysis, as shown in pigs (Seynaeve et al. 2000). The capability of the small intestine to digest phytic acid seems to be very small due to low phytase activity of the small-intestinal digesta and rapid digesta passage through this segment. In rats, the intestinal brush border phytase activity contributes to the phytate digestion, but in rabbits this activity is low (Cooper \& Gowing, 1983). Specific phytase activities of the caecal and colonic contents were 2- to 3-fold higher than those of the gastric and small-intestinal contents. Moreover, the retention time of digesta in the ileo-rectal segment of rabbits is long; 7-24h (Carabaño \& Piquer, 1998). Thus, the hindgut appears to be the segment with the highest capacity to hydrolyse phytic acid in rabbits. Similarly, Seynaeve et al. (2000) observed in pigs that about five times more phytic acid was degraded in the hindgut than proximally to the ileo-caecal valve.

$\mathrm{Ca}$ is a major macroelement in animal diets. This divalent cation is generally in excess of a molar ratio of $6: 1$ with phytate. Solubility of calcium phytate at mildly acidic and neutral $\mathrm{pH}$ is very low (Scheuermann et al. 1988). Inhibition of phytic acid hydrolysis by $\mathrm{Ca}$ has been reported in experiments with poultry (for a review, see Ravindran et al. 1995), pigs (Sandberg et al. 1993; Lantzsch et al. 1995) and rats (Nahapetian \& Young, 1980). In the present study, phytic acid hydrolysis was inhibited in a dose-dependent manner by $\mathrm{Ca}$ cations. The faecal concentration of total and phytate $\mathrm{P}$ correlated with concentration of $\mathrm{Ca}$, presumably because of formation of insoluble complexes containing both elements.

The present results suggest that inorganic phosphates hinder phytic acid hydrolysis by caecal micro-organisms; the inhibitory effect of phosphate anions, however, was less pronounced than that of $\mathrm{Ca}$ cations. A similar negative feedback mechanism exists in A. niger phytase, which is often used as a feed supplement in poultry and pigs (Dvořáková et al. 1997). Limited information is available on the effect of inorganic phosphates on phytic acid hydrolysis in the animal digestive tract. Seynaeve et al. (2000) found that phytate hydrolysis in the ileum of pigs was reduced by the addition of mineral phosphates. Similarly, results of Ravindran et al. (2000) have indicated that high dietary concentrations of inorganic phosphates have inhibitory effects on phytase activity in broiler chickens. 
Many studies have reported the beneficial effect of supplemental phytases produced by fungi of the Aspergillus genus on utilization of $\mathrm{P}, \mathrm{N}$ and minerals in poultry and pigs (for a review, see Pallauf \& Rimbach, 1997). Gutiérrez et al. (2000) showed that the supplementation of $A$. niger phytase of a diet of growing rabbits significantly improved $\mathrm{P}$ and $\mathrm{N}$ digestibility by 24 and $7 \%$, respectively. In the opinion of these authors, the capacity of endogenous (caecal) phytase to release $\mathrm{P}$ from phytic acid is limited in rabbits. It follows from our results that rabbits digest phytic acid fairly efficiently; a high concentration of phosphates in faeces, however, suggests that the ability of rabbits to absorb phosphates liberated in the hindgut may be limited by high digesta viscosity, a low intestinal surface:digesta volume, and possibly also by insufficient transporting capacity of the epithelium. The addition of exogenous phytase to rabbit feeds could increase phytic acid hydrolysis in the upper part of the digestive tract and eliminate the need for inorganic phosphate supplements.

\section{Acknowledgements}

This study was funded by the Grant Agency of the Czech Republic (project no. 524/99/0101) and by the Academy of Sciences of the Czech Republic (project no. S5045012).

\section{References}

Association of Official Analytical Chemists (1980) Official Methods of Analysis, 13th edn., pp. 125-142. Washington, DC: Association of Official Analytical Chemists.

Barlet JP, Davicco MJ \& Coxam V (1995) Intestinal absorption of inorganic phosphorus. Reproduction, Nutrition, Development 35, 475-489.

Berner W, Kinne R \& Murer H (1976) Phosphate transport into brush-border membrane vesicles isolated from rat small intestine. Biochemical Journal 160, 467-474.

Carabaño R \& Piquer J (1998) The digestive system of the rabbit. In The Nutrition of the Rabbit, pp. 1-16 [C de Blas and J Wiseman, editors]. Wallingford, UK: CABI Publishing.

Cooper JR \& Gowing HS (1983) Mammalian small intestinal phytase (EC 3.1.3.8). British Journal of Nutrition 50, 673-678.

de Blas C \& Mateos GG (1998) Feed formulation. In The Nutrition of the Rabbit, pp. 241-253 [C de Blas and J Wiseman, editors]. Wallingford, UK: CABI Publishing.

Dušková D, Marounek M \& Březina P (2001) Determination of phytic acid in feeds and faeces of pigs and poultry by capillary isotachophoresis. Journal of the Science of Food and Agriculture 81, 36-41.

Dvořáková J, Volfová O \& Kopecký J (1997) Characterization of phytase produced by Aspergillus niger. Folia Microbiologica 42, 349-352.

Fan MZ, Archbold T, Sauer WC, Lackeyram D, Rideout T, Gao YX, de Lange CFM \& Hacker RR (2001) Novel methodology allows simultaneous measurement of true phosphorus digestibility and the gastrointestinal endogenous phosphorus outputs in studies with pigs. Journal of Nutrition 131, $2388-2396$.

Gutiérrez I, García J, Carabaño R, Mateos GG \& de Blas JC (2000) Effect of exogenous phytase on phosphorus and nitrogen digestibility in growing-finishing rabbits. World Rabbit Science 8, Suppl. 1, 277-281.

Hattenhauer O, Traebert M, Murer H \& Biber J (1999) Regulation of small intestinal Na-P(i) type IIb cotransporter by dietary phosphate intake. American Journal of Physiology 277, G756-G762.

Jehl N \& Gidenne T (1996) Replacement of starch by digestible fibre in feed for the growing rabbit. Consequences for microbial activity in the caecum and on incidence of digestive disorders. Animal Feed Science and Technology 61, 193-204.

Lantzsch H-J, Wjst S \& Drochner W (1995) The effect of dietary calcium on the efficacy of microbial phytase in rations for growing pigs. Journal of Animal Physiology and Animal Nutrition 73, 19-26.

Liu J, Bollinger DW, Ledoux DR \& Veum TL (2000) Effects of dietary calcium:phosphorus ratios on apparent absorption of calcium and phosphorus in the small intestine, cecum, and colon of pigs. Journal of Animal Science 78, 106-109.

Marounek M, Dušková D, Skřivanová V \& Savka OG (2000) Isotachophoretic determination of phytic acid in the feed and faeces of rabbits. World Rabbit Science 8, Suppl. 1, $321-326$.

Mateos GG \& de Blas C (1998) Minerals, vitamins and additives. In The Nutrition of the Rabbit, pp. 145-175 [C de Blas and J Wiseman, editors]. Wallingford, UK: CABI Publishing.

Morse D, Head HH \& Wilcox CJ (1992) Disappearance of phosphorus in phytate from concentrates in vitro and from rations fed to lactating dairy cows. Journal of Dairy Science $\mathbf{7 5}$, 1976-1986.

Murer H, Hernando N, Forster I \& Biber J (2001) Molecular mechanisms in proximal tubular and small intestinal phosphate reabsorption. Molecular Membrane Biology 18, 3-11.

Nahapetian A \& Young VR (1980) Metabolism of ${ }^{14} \mathrm{C}$-phytate in rats: effect of low and high dietary calcium intakes. Journal of Nutrition 110, 1458-1472.

Pallauf J \& Rimbach G (1997) Nutritional significance of phytic acid and phytase. Archives of Animal Nutrition 50, 301-319.

Perez JM, Lebas F, Gidenne T, Maertens L, Xiccato G, Parigi-Bini R, Dalle Zotte A, Cossu ME, Carazzolo A, Villamide MJ, Carabaño R, Fraga MJ, Ramos MA, Cervera C, Blas E \& Fernandez A (1995) European reference method for in vivo determination of diet digestibility in rabbits. World Rabbit Science 3, 41-43.

Peterson GL (1978) A simplified method for analysis of inorganic phosphate in the presence of interfering substances. Analytical Biochemistry 84, 164-172.

Raun A, Cheng E \& Burroughs W (1956) Phytate phosphorus hydrolysis and availability to rumen microorganisms. Agricultural and Food Chemistry 4, 869-871.

Ravindran V, Bryden WL \& Kornegay ET (1995) Phytates: occurrence, bioavailability and implications in poultry nutrition. Poultry and Avian Biology Reviews 6, 125-143.

Ravindran V, Cabahug S, Ravindran G, Selle PH \& Bryden WL (2000) Responses of broiler chickens to microbial phytase supplementation as influenced by dietary phytic acid and non-phytate phosphorus levels. II. Effects on apparent metabolisable energy, nutrient digestibility and nutrient retention. British Poultry Science 41, 193-200.

Reddy NR, Sathe SK \& Salunkhe DK (1982) Phytates in legumes and cereals. Advances in Food Research 28, 1-92.

Sandberg A-S, Larsen T \& Sandström B (1993) High dietary calcium level decreases colonic phytate degradation in pigs fed a rapeseed diet. Journal of Nutrition 123, 559-566.

Scheuermann SE, Lantzsch H-J \& Menke KH (1988) In vitro und in vivo Untersuchungen zur Hydrolyse von Phytat. I. Löslichkeit von Phytat (In vitro and in vivo experiments on 
the hydrolysis of phytate I. Solubility of phytate). Journal of Animal Physiology and Animal Nutrition 60, 55-63.

Seynaeve M, Janssens G, Hesta M, Van Nevel C \& De Wilde RO (2000) Effects of dietary $\mathrm{Ca} / \mathrm{P}$ ratio, $\mathrm{P}$ level and microbial phytase supplementation on nutrient digestibilities in growing pigs: breakdown of phytic acid, partition of $\mathrm{P}$ and phytase activity along the intestinal tract. Journal of Animal Physiology and Animal Nutrition 83, 193-204.
Taylor TG \& Coleman JW (1979) A comparative study of the absorption of calcium and the availability of phytatephosphorus in the golden hamster (Mesocricetus auratus) and the laboratory rat. British Journal of Nutrition 42, 113-119.

Yanke LJ, Bae HD, Selinger LB \& Cheng K-J (1998) Phytase activity of anaerobic ruminal bacteria. Microbiology 144, $1565-1573$. 